\title{
Degree of Milling Effect on Cold Water Rice Quality
}

\author{
Ujjwol Subedi ${ }^{@}$, Roman Karki, Pravin Ojha, Achyut Mishra, Man Bahadur Shrestha and Durga Man Singh Dongol \\ Food Research Division, Nepal Agricultural Research Council, Khumaltar, Lalitpur, Nepal; @: uj.subedi@gmail.com; \\ RK<karki.roman@gmail.com>; PO<projha84@gmail.com>; AM <achyutmishra2000@gmail.com>; MBS \\ <shrestham6@hotmail.com>; DMSD<durgadongol@yahoo.com>
}

Received 11 Jan 2018, Revised 25 Feb 2018, Accepted 15 March, Published 28 April 2018

Scientific Editors: Shree Bhagwan Thakur, Tek Prasad Gotame, Hari Bahadur KC Copyright (C) 2018 NARC. Permits unrestricted use, distribution and reproduction in any medium provided the original work is properly cited.

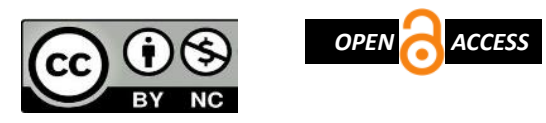

Licensed under the Creative Commons AttributionNonCommercial 4.0 International (CC BY-NC 4.0)

\begin{abstract}
The aim of this study was to examine the effects of degree of milling on various rice parameters such as proximate composition, and cooking properties using mathematical model. The experiments were performed in the laboratory of Food Research Division, Nepal Agricultural Research Council. The three different medium type rice varieties of Nepal (Lumle-2, Chhomrong and Machhapuchre-3) were exposed to five different degrees of milling (0\%, 6\%,8\%,10\% and $12 \%)$. The degree of milling (DM) level significantly $(\mathrm{P} \leq 0.05)$ affected the milling recovery; head rice yield, nutrient content as well as cooking properties of the rice. Increase in DM resulted in further reduction of protein content, fat content, minerals, milled rice and head rice yield after bran layer was further removed. A positive correlation between DM used in present model, amylose content, kernel elongation and gruel solid loss was observed, however, with an increase in DM; amylose content, kernel elongation and gruel solid loss were found to be increased. Adopting 6 to $8 \%$ DM for commercial milling of rice might help to prevent quantitative, qualitative and nutritional loss along with retention of good cooking characteristics.
\end{abstract}

Keywords: Amylose, Cold water rice, Elongation ratio, Gruel loss, Head rice recovery

\section{सारंश}

चामललाई विभिन्न अनुपातहरुमा पोलिशिंग गर्दा चामलको कुटानी गुणस्तर, पौष्टिक, रासायनिक तत्व र पाकेको चामलको गुणहरुमा आउने परिवर्तनलाई गणितिय ढाँचामा प्रस्तुत गरिएको छ। यस अध्ययनमा लुम्ले-२ छोमरोड़ र माछापुच्छ-३ गरी ३ प्रकारका नेपाली धानका जातहरुलाई $४$ फरक फरक पोलिशिंग $०$, ६, ५, १० र १२ मा पोलिशिंग गरी तुलना गरियो। पोलिशिंग प्रतिशतले चामलको कुटानी गुणस्तर, पैष्टिक र रासायनिक तत्व, पकाएको चामल वा भातको गुणहरुमा असर गरेको पाइयो । सग्लो चामल, प्रोटिन, चिल्लो पदार्थ, खानिज, फाइवरहरुको मात्रा पोलिशिंग अनुपातको बद्धिसँगै घट्दै गएको पाइयो भने कार्वोहाइड्टेट, एमाइलोज, पाकेको चामलको लम्वाईको बद्धि अनुपात र भातको माडमा हुने ठोस पदार्थको क्षयको मात्रा बृद्धि हुँदे गएको पाइयो । समग्रमा व्यवसायिक रुपमा चामलको पोलिशिंग अनुपात ६ देखि $५ \%$ कायम गरिएमा खाद्य तथा पोषण सुरक्षा दुबैमा सहयोग हुने पाइयो ।

\section{INTRODUCTION}

Rice (Oryza sativa L.) is an important cereal grain, which is a staple food for more than half of the world's population (Xiang et al 2015). Rice is usually consumed as cooked whole grains, it is also processed to puffed rice or flour and starch that can be further formulated into various products (Joshi et al 2013). Physicochemical properties and rice grain quality are mainly influenced by rice genotypes (Iturriaga et al 2004), surrounding environmental factors, where they are grown (Singh et al 2005), protein content (Marco and Rosell 2008), amylose content (Varavinit et al 2003), gelatinization temperature, gel consistency (Bhattacharya et al 2011) and milling method (Suksomboon and Naivikul 2006).

Rice farming dominates the agriculture sector and national economy of Nepal as it covers $42 \%$ of total cultivable area under food grains and $51.6 \%$ of the total food grain production of the country (MoAD 2013). According to MoAD (2015) food security may highly depending on the rice production as it contributes $7 \%$ and $20 \%$ gross domestic product and agricultural gross domestic product (GDP), respectively. Similarly, in Nepal rice is cultivated under varying topography, climates and altitudes; from 60 meters to 3050 meters above sea level (MoAD 2015). A total of 57 rice varieties have been released and 17 rice varieties have been registered in the country (NARC 2014).

Around $40-80 \%$ of the total calorie intake in a regular Asian diet is contributed by rice (Bhattacharya et al 2011). The net protein utilization value for rice is 63 , compared with 49 for wheat and 36 for maize; rice is relatively 
non-allergenic and has an enduring palatability too (Pillaiyar 1988). Though rice is gifted with these advantages, malnutrition persists in rice consuming areas. This is mainly due to the adoption of improper handling practices particularly in storage and milling (Paramita et al 2002). Generally, rice is consumed as a whole, kernel of white rice obtained after removal of husk, bran and germ from the surface of the grain; therefore, milling has profound effect on its nutrient composition (Lamberts et al 2007). DM has a great influence on rice quality such as physicochemical properties, nutritional value, cooking and eating quality (Mohapatra and Bal 2007) as well as on biological components like amylase activity and peptidase activities (Tran et al 2004). Lumle-2, Chhomrong and Machhapuchhre-3 are some of the popular medium types, non-waxy (Subedi et al 2016), mid to high hill cold water rice varieties of Nepal (NARC 2014). However, the effects of DM on the quality parameters of these rice varieties were still needed to be studied for obtaining high-quality rice after milling. Therefore, the overall objective of this study was to investigate the effects of DM on the rice quality.

\section{MATERIALS AND METHODS}

Paddy samples of Lumle-2, Chhomrong and Machhapuchre-3 varieties were obtained from Regional Agricultural Research Centre, Lumle, Kaski, Pokhara and the samples were analyzed in the laboratory of Food Research Division, Nepal Agricultural Research Council, Khumaltar, Lalitpur. The paddy samples were shelled in the Otake Rice Sheller (impeller husker, FCS type, Otake Co., Oharu, Japan) to obtain brown rice and polished in Yamamoto Rice polisher (Friction type, VP-31T, Yamamoto Co., Tendou, Japan) to obtain brown rice $(0 \%)$ and milled rice of $6 \%, 8 \%, 10 \%, 12 \%$ degree of milling for further analysis.

\section{Degree of Milling}

The obvious and probably defining way to judge the DM is to consider what percentage by weight of the brown rice has been removed as bran during milling. The mean grain weight of the brown rice (mBR) and of the milled rice (mMR) was calculated according to Bhattacharya (2011).

$$
D M=\frac{m B R-m M R}{m B R} \times 100 \%
$$

Physical Analysis

Thousand Kernels Weight

A thousand kernels were counted from the sample and weight was determined using the electronic balance and expressed in gram. Milling recovery and head rice yield was calculated as follows:

Milling recovery $\%=($ Weight of milled rice/ Weight of paddy $) \times 100 \%$

Head rice yield $\%=($ Weight of head rice/ Weight of milled rice $) \times 100 \%$

\section{Proximate Composition}

Determination of moisture content (hot air oven method), crude protein (Micro-Kjeldahl), crude fat (ether extraction method), total ash and minerals (iron, phosphorous, and calcium) were done based on AOAC (2000) standard methods. Total carbohydrate content was determined according to Thomas et al (2013).

Total carbohydrate $(\%)=100 \%-(\%$ Moisture + Protein + Fat + Ash $)$

\section{Amylose Content}

Amylose content in the rice samples was determined based on the iodine-binding procedure as described by Juliano (1972). In brief, rice was milled and passed through a 100-mesh sieve. $100 \mathrm{mg}$ of samples were weighted and $1 \mathrm{ml}$ of ethanol $(95 \%)$ and $9 \mathrm{ml}$ of standardized $1 \mathrm{NNaOH}$ were added. The samples were heated for 10 minutes in the boiling water bath to gelatinize the starch, cooled and transferred quantitatively and made up volume $100 \mathrm{ml}$ with distilled water. Then, $5 \mathrm{ml}$ of the solution was pipetted into another 100 volumetric flask, $1 \mathrm{ml}$ of $1 \mathrm{~N}$ acetic acid and $2 \mathrm{ml}$ of iodine solution $(0.2 \mathrm{~g}$ iodine and $2 \mathrm{~g}$ potassium iodide in $100 \mathrm{ml}$ aqueous solution) were added. The solution was made up $100 \mathrm{ml}$ with distilled water and let stand for 20 minutes. The absorbance of the solution at $620 \mathrm{~nm}$ was measured in the UV-spectrophotometer setting absorbance 0 for blank. The amylose content in samples was measured according to the standard curve prepared using standard amylose (amylose extracted from potato, Sigma Aldrich Co. USA).

Cooking Quality of Rice

Cooking properties of the rice samples were determined based on available standard procedures (Batcher et al 1956, Singh et al 2005, Thomas et al 2013).

\section{Minimum Cooking Time}

Rice samples $(2 \mathrm{~g})$ were cooked in a tube at around $90^{\circ} \mathrm{C}$ with distilled water $(20 \mathrm{ml})$ in a boiling water bath. The minimum time required for cooking was estimated by pressing the cooked rice samples between two glass slides (till no white core was left) by observing few cooked rice samples at regular time intervals. 
Gruel Solid Loss

To measure the gruel solid loss, the gruel liquor obtained during the experiment for water uptake ratio was drained on tarred crucible and was evaporated on boiling water bath and placed into the hot air oven until it was completely dry. The dry solid obtained was weighed and percentage of gruel solid loss was calculated.

$$
\text { Gruel loss } \%=\frac{\text { Weight of the residue }}{\text { Weight of the sample (rice) }} \times 100
$$

Elongation Ratio

To determine elongation ratio, twenty random kernels of each rice sample were taken, their length was measured and cooked to the minimum cooking time. The cooked kernels were taken out and placed on blotting paper with the help of bent wire to absorb excess water. The length of cooked rice kernels was measured by spacing on graph paper. Elongation ratio was calculated by dividing the average length of cooked kernel by its original length as given

$$
\text { Elongation ratio }=\frac{\text { Average length of cooked kernel }(\mathrm{mm})}{\text { Average length of uncooked kernel }(\mathrm{mm})} \times 100 \%
$$

Statistical Analysis

IBM SPSS Statistics Version 20 and Microsoft Office Excel 2007 were used for the statistical analysis and data interpretation. The data were analyzed by one-way analysis of variance (ANOVA) using SPSS programming at $5 \%$ level of significance. The significant differences between these parameters were studied by using LSD at 5\% level of significance.

\section{RESULTS}

Milling Recovery

Milling recovery (\%) of Lumle-2, Chhomrong and Machhapuchhre-3 varieties decreased from 83.37 \pm 0.15 to $73.51 \pm 0.01,80.85 \pm 0.06$ to $71.79 \pm 0.29$ and $80.02 \pm 0.20$ to $71.54 \pm 0.04$ respectively at $0 \%$ to $12 \%$ DM. With increasing degree of milling, milling recovery of rice showed linear trend with negative slope as shown in Figure 1. The negative slopes indicated the decrease in milling recovery of the rice varieties with increasing degree of milling. The mathematical equations for the rate of decrease in milling recovery with increasing DM are shown in Table 1.

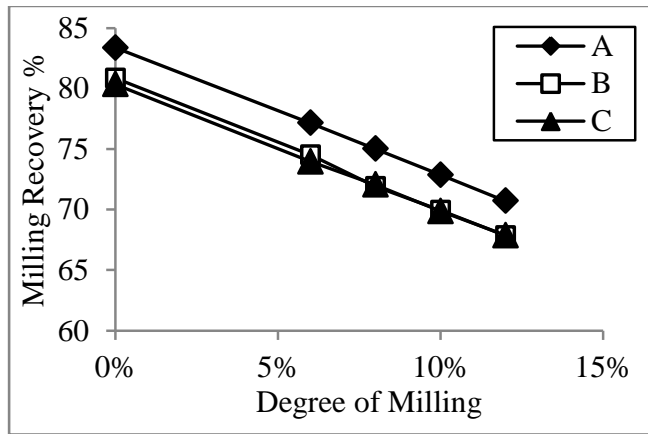

Table 1. Modeling of milling recovery of rice with different

\begin{tabular}{|c|c|c|c|}
\hline Parameters & $\begin{array}{l}\text { (A) } \\
\text { Lumle-2 }\end{array}$ & $\begin{array}{l}\text { (B) } \\
\text { Chhomrong }\end{array}$ & $\begin{array}{r}(\mathrm{C}) \\
\text { Machhapuchhre-3 }\end{array}$ \\
\hline Equation & $\begin{array}{l}\mathrm{Y}= \\
105.4 \mathrm{X}+ \\
83.41\end{array}$ & $\begin{array}{l}Y=-109.2 X \\
+80.86\end{array}$ & $Y=-104.0 X+80.31$ \\
\hline Slope & -105.4 & -109.2 & -104 \\
\hline $\mathrm{R}^{2}$ & 0.999 & 0.999 & 0.999 \\
\hline
\end{tabular}
degree of milling

Figure 1. Effect of degree of milling on milling recovery of rice.

Head Rice Recovery

Head rice recovery showed linear trend with the DM for all rice varieties examined as shown in Figure 2. The head rice recovery decreased with increase in the degree of milling, the negative slopes indicated the decrease of head rice recovery with increasing degree of milling. Head rice (\%) of Lumle-2, Chhomrong and Machhapuchhre-3 varieties decreased from $82.18 \pm 0.01$ to $68.68 \pm 0.15,84.99 \pm 0.05$ to $56 \pm 0.05$ and $76.54 \pm 0.01$ to $55.07 \pm 0.03$ respectively at $0 \%$ to $12 \% \mathrm{DM}$. The mathematical equations for the rate of decrease in head rice recovery with increasing DM are shown in Table 2. 


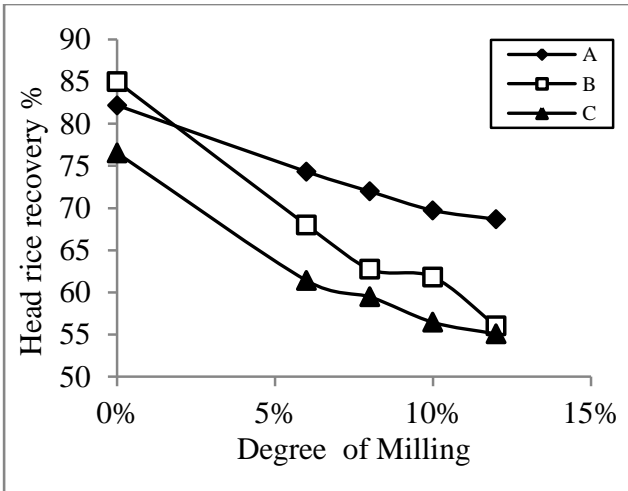

Table 2. Modeling of head rice recovery with different degree of milling

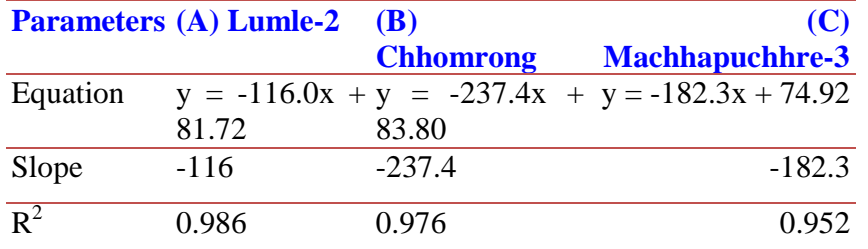

Figure 2. Effect of degree of milling on head rice recovery of rice.

\section{Thousand Kernels Weight}

Thousand Kernels Weight of rice also showed the linear relationship for all rice varieties tested as shown in Figure 3. The Thousand Kernels Weight decreased with increase in the degree of milling, the negative slopes indicated the decrease of the Kernel Weight with increasing degree of milling. Thousand Kernel Weight (g) of Lumle-2, Chhomrong and Machhapuchhre-3 varieties decreased from 24.55 \pm 0.02 to $21.61 \pm 0.04,25.03 \pm 0.18$ to $23.35 \pm 0.14$ and $20.06 \pm 0.06$ to $16.99 \pm 0.01$ respectively at $0 \%$ to $12 \% \mathrm{DM}$. The mathematical equation for the rate of decrease in thousand kernels weight with increasing DM is shown in Table 3.

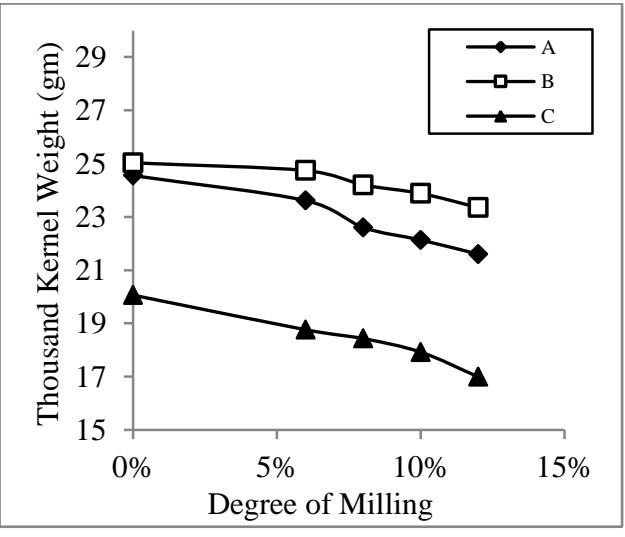

rice.
Table 3. Modeling of thousand kernel weight of rice with different degree of milling

\begin{tabular}{lllr}
\hline Parameters & (A) & (B) & $\begin{array}{r}\text { (C) } \\
\end{array}$ \\
& Lumle-2 & Chhomrong & Machhapuchhre-3 \\
\hline Equation & $\mathrm{Y}=-25.19 \mathrm{X}=-13.67 \mathrm{X}+$ & $\mathrm{Y}=-24.14 \mathrm{X}+$ \\
& +24.71 & 25.22 & 20.17 \\
\hline Slope & -25.19 & -13.67 & -24.14 \\
\hline $\mathrm{R}^{2}$ & 0.961 & 0.967 & 0.969 \\
\hline
\end{tabular}

Figure 3. Effect of degree of milling on thousand kernel weight of

\section{Fat Content}

Fat content of the rice varieties was found to be decreasing with increasing degree of milling. Fat content $(\%)$ of Lumle-2, Chhomrong and Machhapuchhre-3 varieties decreased from 3.07 \pm 0.10 to $0.82 \pm 0.04,2.57 \pm 0.03$ to $0.80 \pm 0.05$ and $2.74 \pm 0.03$ to $0.83 \pm 0.01$ respectively at $0 \%$ to $12 \% \mathrm{DM}$. The fat content showed linear relationship as shown in Figure 4, where the negative slopes indicated the decrease in the fat content. The mathematical equations for the rate of decrease in fat content with increasing DM are shown in Table 4.

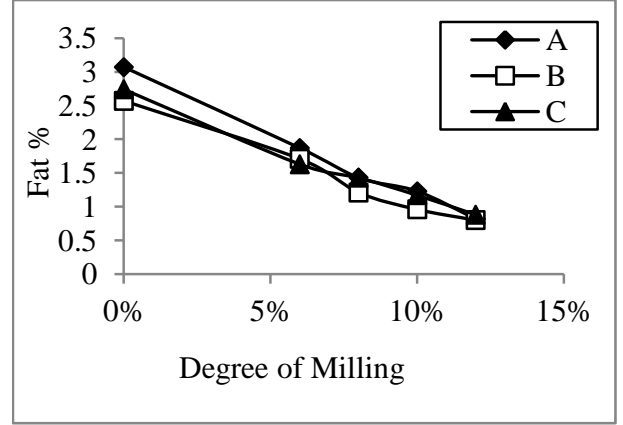

Table 4. Modeling of fat content of rice with different degree of milling

\begin{tabular}{lllr}
\hline Parameters & (A) & (B) & (C) \\
& Lumle-2 & Chhomrong & Machhapuchhre-3 \\
\hline Equation & $\mathrm{Y}=$ & $-\mathrm{Y}=-15.40 \mathrm{X}+$ & $\mathrm{Y}=-15.37 \mathrm{X}+$ \\
& $18.66 \mathrm{X}$ & +2.558 & 2.677 \\
& 3.027 & & \\
\hline Slope & -18.66 & -15.40 & -15.37 \\
\hline $\mathrm{R}^{2}$ & 0.993 & 0.984 & 0.988 \\
\hline
\end{tabular}

Figure 4. Effect of degree of milling on fat content of rice.

Protein Content 
Protein content of the rice varieties were found to be decreasing with increasing degree of milling. Protein content (\%) of Lumle-2, Chhomrong and Machhapuchhre-3 varieties decreased from 12.55 \pm 0.32 to 9.91 \pm 0.11 , $8.41 \pm 0.16$ to $7.30 \pm 0.20$ and $9.96 \pm 0.36$ to $8.15 \pm 0.03$ respectively at $0 \%$ to $12 \% \mathrm{DM}$. The protein content also showed linear relationship as shown in Figure 5, where the negative slope indicates the decrease in the protein content. The mathematical equations for the rate of decrease in protein content with increasing DM have been shown in Table 5.

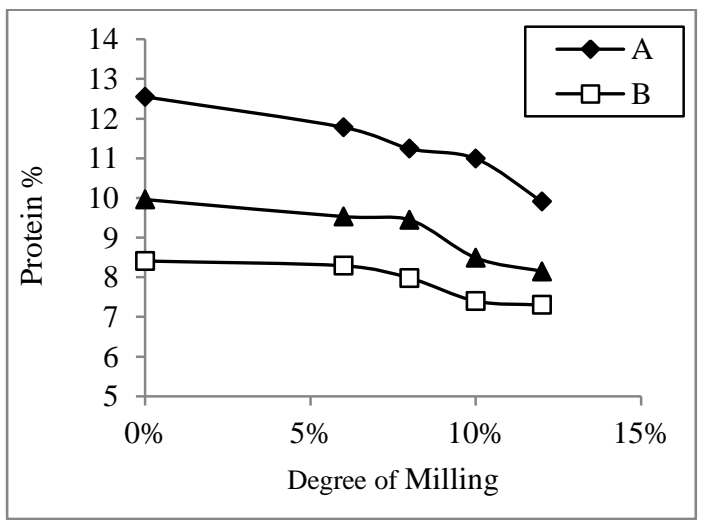

Table 5. Modeling of protein content of rice with different degree of milling

\begin{tabular}{|c|c|c|c|}
\hline Parameters & (A) & (B) & (C) \\
\hline & Lumle-2 & Chhomrong & Machhapuchhre-3 \\
\hline Equation & $Y=-20.24 X$ & $Y=-9.853 \mathrm{X}$ & $\mathrm{Y}=-14.97 \mathrm{X}+10.19$ \\
\hline & +12.75 & 8.585 & \\
\hline Slope & -20.24 & -9.853 & -14.97 \\
\hline $\mathrm{R}^{2}$ & 0.908 & 0.802 & 0.819 \\
\hline
\end{tabular}

Figure 5. Effect of degree of milling on protein content of rice.

Total Ash Content

Total ash content of the rice varieties was found to be decreasing with increasing degree of milling. Total ash content (\%) of Lumle-2, Chhomrong and Machhapuchhre-3 varieties decreased from 1.81 \pm 0.04 to $0.72 \pm 0.02$, $1.65 \pm 0.06$ to $0.85 \pm 0.01$ and $1.84 \pm 0.03$ to $0.99 \pm 0.04$ respectively at $0 \%$ to $12 \% \mathrm{DM}$. The total ash content followed linear trend as shown in Figure 6 where the negative slopes indicates the decrease in the total ash content. The mathematical equations for the rate of decrease in total ash content with increasing DM are shown in Table 6.

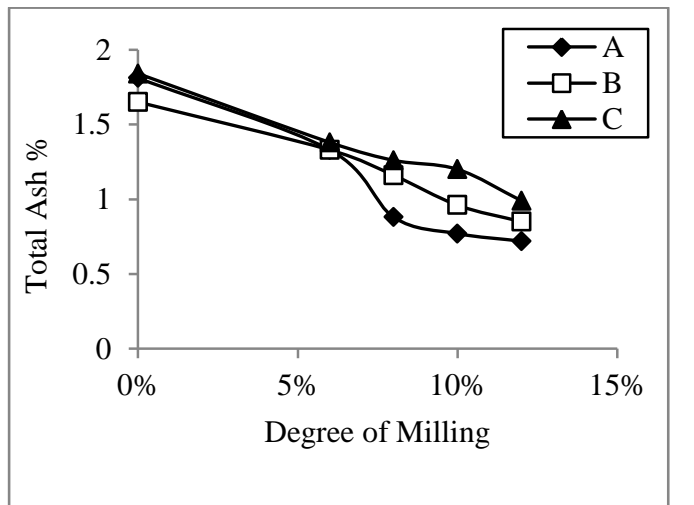

Table 6. Modeling of total ash content of rice with different degree of milling

\begin{tabular}{lllr}
\hline Parameters & (A) & (B) & $($ C) \\
& Lumle-2 & Chhomrong & Machhapuchhre-3 \\
\hline Equation & $\mathrm{Y}=-9.801 \mathrm{X}+\mathrm{Y}=-6.816 \mathrm{X}+$ & $\mathrm{Y}=-6.820 \mathrm{X}+$ \\
& 1.807 & 1.680 & 1.825 \\
& -9.801 & -6.816 & -6.820 \\
\hline Slope & 0.948 & 0.983 & 0.986 \\
\hline $\mathrm{R}^{2}$ & & & \\
\hline
\end{tabular}

Figure 6. Effect of degree of milling on total ash content of rice.

\section{Amylose Content}

The amylose content of the rice varieties was found to be increasing with increase in the degree of milling. Amylose content (\%) of Lumle-2, Chhomrong and Machhapuchhre-3 varieties increased from 26.73 \pm 0.14 to $27.36 \pm 0.05,26.96 \pm 0.02$ to $28.54 \pm 0.10$ and $26.95 \pm 0.08$ to $27.63 \pm 0.04$ respectively at $0 \%$ to $12 \%$ DM. Amylose content increased linearly (Figure 7) shows the increase of amylose with an increase in the degree of milling. The mathematical equations for the rate of increase in amylose content with increasing DM are shown in Table 7.

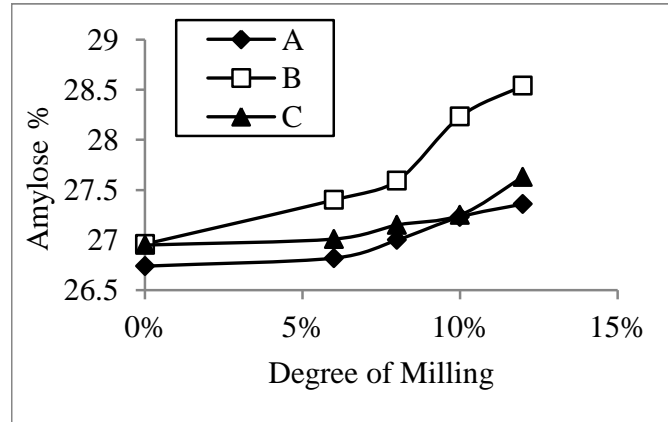

Table 7. Modeling of amylose content of rice with different degree of milling

\begin{tabular}{lllr}
\hline Parameters & $\begin{array}{l}\text { (A) } \\
\text { Lumle-2 }\end{array}$ & $\begin{array}{l}(\text { B }) \\
\text { Chhomrong }\end{array}$ & $\begin{array}{r}\text { Machhapuchhre-3 } \\
\text { Equation }\end{array}$ \\
& $\mathrm{Y}$ & $=\mathrm{Y}=13.10 \mathrm{X}+\mathrm{Y}=4.943 \mathrm{X}+26.84$ \\
& $5.259 \mathrm{X}$ & +26.8 & \\
\hline Slope & 26.65 & & 4.943 \\
\hline $\mathrm{R}^{2}$ & 5.259 & 13.10 & 0.718 \\
\hline
\end{tabular}


Figure 7. Effect of degree of milling on amylose content of rice

Total Carbohydrate Content

Total carbohydrate content of the rice varieties increased with increasing the degree of milling (Figure 8, Table 8). Carbohydrate content showed linear relationship with the degree of milling. Total carbohydrate content (\%) of Lumle-2, Chhomrong and Machhapuchhre-3 varieties increased from $68.57 \pm 0.34$ to $74.55 \pm 0.42,73.37 \pm 0.21$ to $77.05 \pm 0.24$ and $71.46 \pm 0.18$ to $75.98 \pm 0.21$ respectively at $0 \%$ to $12 \% \mathrm{DM}$.

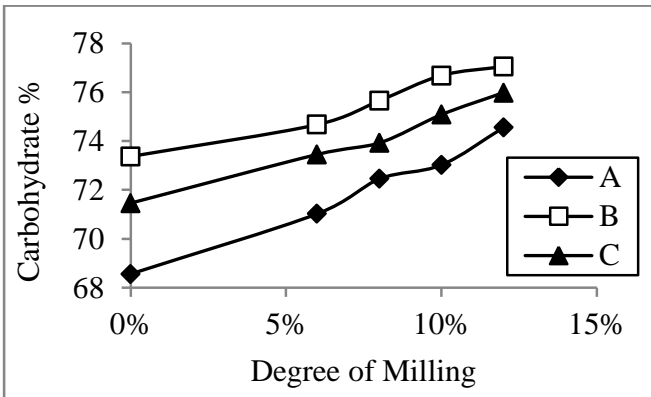

Table 8. Modeling of total carbohydrate content of rice with different degree of milling

\begin{tabular}{|c|c|c|c|}
\hline \multirow[t]{2}{*}{ Parameters } & (A) & (B) & (C) \\
\hline & Lumle-2 & Chhomrong & Machhapuchhre-3 \\
\hline Equation & $\begin{array}{l}Y=48.82 X \\
+68.40\end{array}$ & $\begin{array}{l}Y=32.07 X+ \\
73.17\end{array}$ & $Y=37.04 X+71.31$ \\
\hline Slope & 48.82 & 32.07 & 37.04 \\
\hline $\mathrm{R}^{2}$ & 0.985 & 0.964 & 0.982 \\
\hline
\end{tabular}

Figure 8. Effect of degree of milling on carbohydrate content of rice.

\section{Iron Content}

The iron content of the rice varieties tended to linear decrease with increasing degree of milling (Table 9, Figure 9). Iron content $(\mathrm{mg} / 100 \mathrm{~g})$ of Lumle-2, Chhomrong and Machhapuchhre-3 varieties decreased from $1.37 \pm 0.02$ to $0.35 \pm 0.01,1.77 \pm 0.01$ to $0.39 \pm 0.01$ and $3.04 \pm 0.02$ to $1.51 \pm 0.01$ respectively at $0 \%$ to $12 \%$ DM.

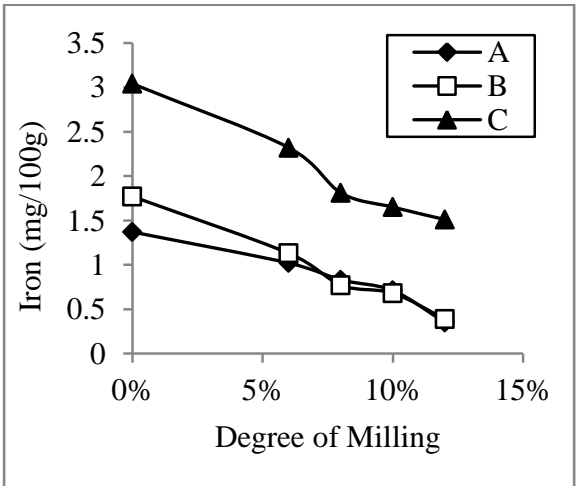

Table 9. Modeling of iron content of rice with different degree of milling

\begin{tabular}{|c|c|c|c|}
\hline Parameters & $\begin{array}{l}\text { (A) } \\
\text { Lumle-2 }\end{array}$ & $\begin{array}{l}\text { (B) } \\
\text { Chhomrong }\end{array}$ & $\begin{array}{r}(\mathrm{C}) \\
\text { Machhapuchhre-3 }\end{array}$ \\
\hline Equation & $\begin{array}{l}Y=-7.967 X \\
+1.429\end{array}$ & $\begin{array}{l}Y=-11.44 \mathrm{X}+ \\
1.772\end{array}$ & $Y=-13.39 X+3.030$ \\
\hline Slope & -7.967 & -11.44 & -13.39 \\
\hline $\mathrm{R}^{2}$ & 0.945 & 0.989 & 0.974 \\
\hline
\end{tabular}

Figure 9. Effect of degree of milling on iron content of rice.

Phosphorous Content

Phosphorous content of the rice varieties decreased with increasing degree of milling (Figure 10, Table 10). The phosphorous content in rice varied substantially according to the varieties. The phosphorus content sharply declined in Lumle -2 rice variety with the increasing milling rate while the decline in phosphorus level was relatively low in Chhomrong and Machhapuchhre-3 varieties (Figure 10). Phosphorous content (mg/100g) of Lumle-2, Chhomrong and Machhapuchhre-3 varieties decreased from 242.07 \pm 0.20 to 215.24 \pm 0.24 , $215.26 \pm 0.10$ to $193.48 \pm 0.38$ and $395.67 \pm 0.66$ to $277.67 \pm 0.15$ respectively at $0 \%$ to $12 \%$ DM.

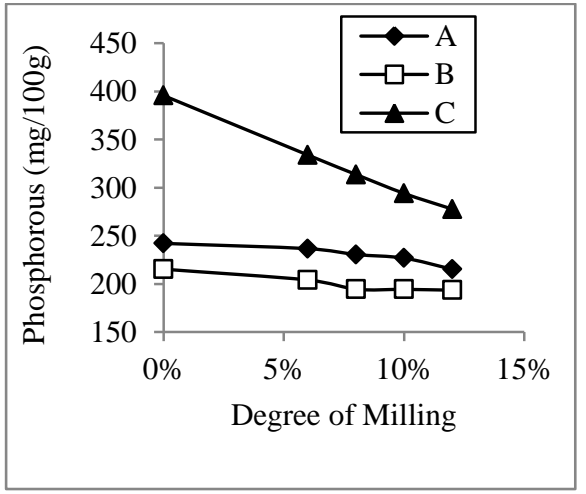

Table 10. Modeling of phosphorous content of rice with different degree of milling

\begin{tabular}{lllr}
\hline Parameters & $\begin{array}{l}\text { (A) } \\
\text { Lumle-2 }\end{array}$ & $\begin{array}{l}\text { (B) } \\
\text { Chhomrong }\end{array}$ & $\begin{array}{r}\text { (C) } \\
\text { Machhapuchhre-3 }\end{array}$ \\
\hline Equation & $\mathrm{Y}=$ & $\mathrm{Y}=-196.3 \mathrm{X}+$ & $\mathrm{Y}=-993.4 \mathrm{X}+394.4$ \\
& $205.6 \mathrm{X}+214.4$ & \\
\hline Slope & 245.0 & & -993.4 \\
\hline $\mathrm{R}^{2}$ & -205.6 & -196.3 & 0.998 \\
\hline
\end{tabular}


Figure 10. Effect of degree of milling on phosphorous content of rice.

Calcium Content

Calcium content of the rice varieties decreased with increasing degree of milling (Figure 11, Table 11). Calcium content $(\mathrm{mg} / 100 \mathrm{~g})$ of Lumle-2, Chhomrong and Machhapuchhre-3 varieties decreased from $17.75 \pm 0.15$ to $12.98 \pm 0.09,17.87 \pm 0.04$ to $13.88 \pm 0.10$ and $31.81 \pm 0.20$ to $26.89 \pm 0.10$ respectively at $0 \%$ to $12 \%$ DM.

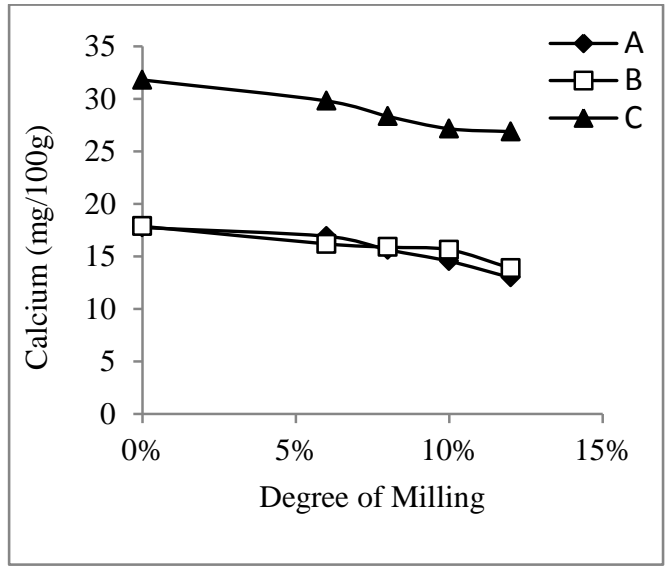

Table 11. Modeling of calcium content of rice with different degree of milling

Parameters (A) (B)

Lumle-2 Chhomrong Machhapuchhre-3

Equation $\quad \mathrm{Y}=-\mathrm{Y}=-29.48 \mathrm{X} \quad \mathrm{Y}=-43.64 \mathrm{X}+$
$38.42 \mathrm{X}++18.01 \quad 31.94$

\begin{tabular}{|c|c|c|c|}
\hline & 18.33 & & \\
\hline Slope & -38.42 & -29.48 & -43.64 \\
\hline $\mathrm{R}^{2}$ & 0.872 & 0.907 & 0.971 \\
\hline
\end{tabular}

Figure 11. Effect of degree of milling on calcium content of rice

Gruel Loss

Gruel loss \% of Lumle-2, Chhomrong and Machhapuchhre-3 varieties increased from 1.51 \pm 0.01 to 7.98 \pm 0.10 ,

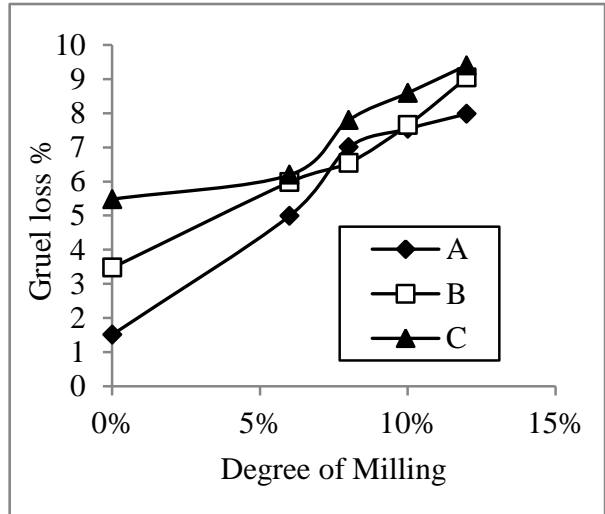
$3.47 \pm 0.08$ to $9.04 \pm 0.03$ and $5.48 \pm 0.01$ to $9.14 \pm 0.11$ respectively at $0 \%$ to $12 \%$ DM. Gruel loss during cooking of the experimented rice showed linear relationship with the degree of milling. The gruel loss increased with increase in the degree of milling (Figure 12, Table 12).

Table 12. Modeling of gruel loss of rice with different degree of milling

\begin{tabular}{|c|c|c|c|}
\hline Parameters & $\begin{array}{l}\text { (A) } \\
\text { Lumle-2 }\end{array}$ & $\begin{array}{l}\text { (B) } \\
\text { Chhomrong }\end{array}$ & $\begin{array}{r}(\mathrm{C}) \\
\text { Machhapuchhre-3 }\end{array}$ \\
\hline Equation & $\begin{array}{l}y=56.78 x \\
+1.715\end{array}$ & $\begin{array}{l}y=44.67 x+ \\
3.319\end{array}$ & $y=33.63 x+5.068$ \\
\hline Slope & 56.78 & 44.67 & 33.63 \\
\hline $\mathrm{R}^{2}$ & 0.967 & 0.982 & 0.898 \\
\hline
\end{tabular}

Figure 12. Effect of degree of milling ongruel loss of rice.

Cooking Time

Cooking time of all rice varieties showed linear relationship with increasing degree of milling (Figure 13, Table 13). The increase in the degree of milling reduced the cooking time significantly. Cooking time (minutes) of Lumle-2, Chhomrong and Machhapuchhre-3 varieties decreased from $30 \pm 1$ to $12 \pm 1,30 \pm 1.5$ to $21 \pm 1$ and $30 \pm 0.5$ to $15 \pm 0.5$ respectively at $0 \%$ to $12 \% \mathrm{DM}$.

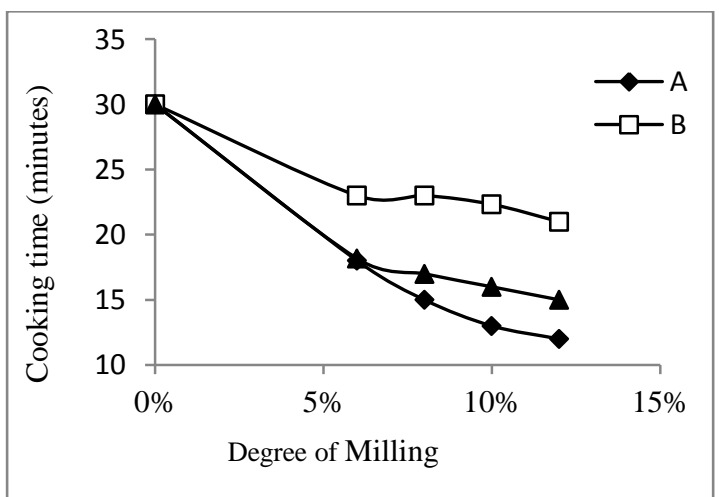

Table 13. Modeling of cooking time of rice with different degree of milling

\begin{tabular}{lllr}
\hline Parameters & $(\mathbf{A})$ & $(\mathbf{B})$ & $(\mathbf{C})$ \\
& Lumle-2 & Chhomrong & Machhapuchhre-3 \\
\hline Equation & $\mathrm{Y}=$ & $-\mathrm{Y}=-72.96 \mathrm{X}+$ & $\mathrm{Y}=-126.6 \mathrm{X}+$ \\
& $155.1 \mathrm{X}$ & +29.12 & 28.35 \\
& 28.77 & & \\
\hline Slope & -155.1 & -72.96 & -126.6 \\
\hline $\mathrm{R}^{2}$ & 0.957 & 0.908 & 0.904 \\
\hline
\end{tabular}

Figure 13. Effect of degree of milling on cooking time of rice 


\section{Elongation Ratio}

Elongation ratio of all three rice varieties was found to be increasing with increasing degree of milling (Figure 14, Table 14). Elongation ratio of Lumle-2, Chhomrong and Machhapuchhre-3 varieties increased from $1.15 \pm 0.08$ to $1.45 \pm 0.03,1.16 \pm 0.02$ to $1.50 \pm 0.05$ and $1.19 \pm 0.08$ to $1.48 \pm 0.02$ respectively at $0 \%$ to $12 \% \mathrm{DM}$.

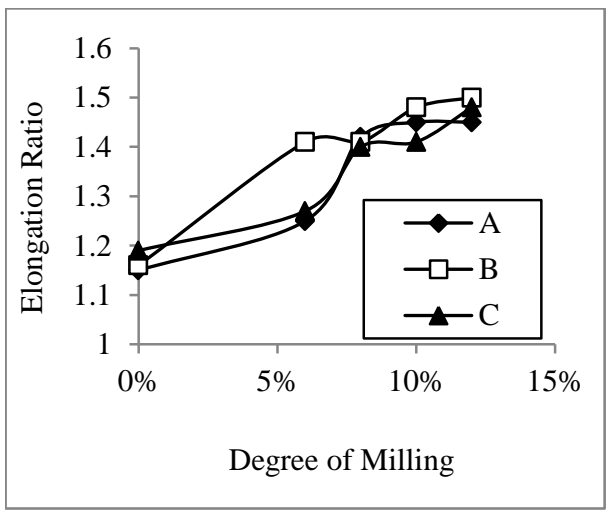

Table 14. Modeling of elongation ratio of rice with different degree of milling

\begin{tabular}{lllr}
\hline Parameters & (A) & (B) & (C) \\
& Lumle-2 & Chhomrong & Machhapuchhre-3 \\
\hline Equation & $\mathrm{y}=2.801 \mathrm{x}$ & $\mathrm{y}=2.863 \mathrm{x}+$ & $\mathrm{y}=2.452 \mathrm{x}+1.173$ \\
& +1.142 & 1.185 & \\
\hline Slope & 2.801 & 2.863 & 2.452 \\
\hline $\mathrm{R}^{2}$ & 0.891 & 0.941 & 0.927
\end{tabular}

Figure 14. Effect of degree of milling on elongation ratio of rice.

\section{DISCUSSION}

From this research significant $(\mathrm{P} \leq 0.05)$ influence of degree of milling $(\mathrm{DM})$ on cold water rice quality parameters were observed. Thapa et al (2010) also reported decreased milling recovery with increasing degree of milling in different slender and bold rice varieties. The reduction in milling recovery is due to loss of endosperm layer from rice kernel along with bran layer as bran during higher degree of milling. Hence the lower degree of milling can increase the milling recovery of rice by preventing the loss of endosperm in bran. Thapa et al (2010) also reported a decrease in head rice recovery with increasing degree of milling in different slender and bold rice varieties. The decrease in head rice recovery and increase in broken rice is due to the removal of a greater amount of bran as well as due to the increased breakage of weak rice kernels with longer milling duration (Saleh and Meullenet 2013, Siebenmorgen and Sun 1994). Hence, head rice recovery can be increased by adopting relatively lower degree of milling.

Environmental factors such as temperature and humidity during ripening and postharvest handling are known to influence grain breakage during milling (Pillaiyar 1988). Head rice recovery is also dependent upon the grain size, shape and appearance. In general, varieties with long or long bold grains and those having chalky grains give lower head rice yields. Varieties having medium, long, slender and translucent grains give the best head rice yield (Pillaiyar 1988). The decrease in thousand kernel weight was due to the removal of a greater amount of rice endosperm as bran from the rice kernel as has been shown by Thapa et al (2010).

The lipid content of rice is very low (1-2\%) and it mainly contains phospholipids; palmitic, stearic, oleic, linoleic and linolenic acids (Kent 1983). Fat content in brown rice and white rice (milled rice) had been shown to be $1.9 \%$ and $0.4 \%$, respectively by Watt and Merrill (1963). The fat contents of rice in present study occurred within the reported ranges. The increase in the degree of milling showed a substantial reduction in fat content of all rice varieties, because rice lipids are known to be localized on the outer caryopsis coat, aleurone and subaleurone layers of rice kernels (Pillaiyar 1988); therefore, milling to a higher degree might have resulted in the removal of a greater amount of lipid from the milled rice. A similar observation was reported by Fujino (1978) that the degree of milling and the milling procedure influence the fat content of milled rice as well as bran. In addition, the major proportion of fat is present in bran and embryo reported by Houston and Kohler (1970). Thus, during milling, most of the fat is removed with bran.

Protein content in brown rice varies from 4.3 to $18.2 \%$ and in milled rice from 5 to $14 \%$ (Juliano et al 1964). Yoshizawa and Ogawa (2004) also reported a decrease in milled rice protein content with increase in milling degree. The reduction in protein is attributed to the removal of outermost layers of rice kernels which are known to be rich in protein content. The amylose content in brown rice was substantially lower than in milled rice at a different degree of milling. This may be due to the presence of bran layer which contributed to the higher dry 
weight of the grain. Removing the bran at different degrees of milling had increased the amylose content. Carbohydrate is, quantitatively, the most important constituent forming about $83 \%$ of the total dry matter of rice. The carbohydrate present in rice grain is mainly starch, cellulose, hemicellulose, fiber, dextrin, and sugar. Starch, a polymer of glucose, occurs in the endosperm as compound polyhedral granules 3 to $10 \mu \mathrm{m}$ in size (Juliano 1972). It is clear that increase in total carbohydrate content with increasing degree of milling was due to the removal of fat, protein and mineral portions in bran.

The ash distribution of brown rice is reported to be $51 \%$ in bran, $10 \%$ in germ, $11 \%$ in polish and $28 \%$ in milled rice (Resurreccion et al 1979). Another study indicated that, most minerals showed a distribution similar to that of ash Juliano and Bechtel (1985). More minerals were present in the aleurone and outer layers of rice kernel than towards centre, thus with increase in degree of milling lead to reduction in total ash and minerals. Watt and Merrill (1963) showed the average iron content $(\mathrm{mg} / 100 \mathrm{~g})$ of brown rice and milled rice were 1.6 and 0.8 , respectively. The phosphorous content in brown rice varied from 215.26 to $445.59 \mathrm{mg} / 100 \mathrm{~g}$, this range was higher than the values reported by Watt and Merrill (1963). A similar observation was reported by Dhaliwal et al (1998), where six different rice varieties of Himachal Pradesh had phosphorous content in brown rice ranging from 404.2 to $470.88 \mathrm{mg} / 100 \mathrm{~g}$. In similar study the phosphorous content of milled rice ranged from 218.04 to $310.08 \mathrm{mg} / 100 \mathrm{~g}$. The analysis showed that higher DM led to a highloss of phosphorous content. According to Watt and Merill (1963), the average calcium content (mg/100gm) of brown rice and milled rice were 32 and 24 , respectively). Our data showed substantial differences among the varieties in relation to the degree of milling. The calcium content in brown rice ranged from (17.749 to 31.813$) \mathrm{mg} / 100 \mathrm{gm}$ and the values were found to be lower than values reported by Watt and Merrill (1963).

Generally, all the varieties possess poor cooking quality if cooked immediately after harvest. The rice become pasty, fail to swell properly, lose more solids in solution and the grains are more cohesive and have a tendency to disintegrate, if cooked soon after harvest. However, such characteristics become progressively less with age in older rice (Grist 1975). According to He (1989), the stored rice needs longer time for cooking, the volume expansion and water absorption increases and total solids in cooking water decreases as compared to fresh rice. Sabularse et al (1991) suggested that the reduction in cooking time with an increase in the degree of milling may be attributed to starch fragmentation and opening up of kernel structure by milling resulting in increased water absorption by rice kernel. Juliano (1985) revealed that cooking time for milled rice were shorter than partially milled brown rice, this was due to absence of the bran layer The differences in the cooking time of brown and milled rice may also be related to differences in starch gelatinization temperature. Rice starch with higher gelatinization temperature has been shown to require longer cooking time than those with lower gelatinization temperature (Juliano and Perez 1983). A similar observation has been shown by Acharya (1991) that fine, long and slender varieties elongate more than coarse and medium varieties. Some varieties expand in size more than others upon cooking. The low elongation ratio may be because of freshly harvested rice samples (Grist 1975). Elongation of rice can be influenced by both length and breadth $(1 / \mathrm{b})$ ratio and amylose contents (Singh et al 2005, Danbaha et al 2011).

\section{CONCLUSION}

Different degree of milling substantially affected the milling, nutritional and cooking properties of the examined rice. Increase in DM resulted in further reduction of protein content, fat content, minerals, milling recovery and head rice yield. A positive correlation between DM, amylose content, kernel elongation and gruel solid loss was observed. With an increase in DM amylose content, kernel elongation and gruel solid loss were found to be increased. Cooking time was found to be inversely proportional with DM. It is suggested that adopting up to 6$8 \% \mathrm{DM}$ for commercial milling of rice might help to prevent quantitative, qualitative and nutritional loss along with retention of good cooking characteristics.

\section{ACKNOWLEDGEMENT}

I would like to thank Regional Agriculture Research Station, Lumle and Food Research Division, Khumaltar for all the materials and technical support. The fund for this study was supported by the NARC under the project entitled "Study on processing and nutritional quality analysis of rice, maize, wheat, legumes and oilseeds genotypes of Nepal".

\section{REFERENCES}

Acharya PP. 1991.Performance of rice varieties in relation to its quality. NRRP-NARC, Parwanipur, Bara, Nepal. AOAC. 2000. Association of Official Analytical Chemists. Official methods of analysis. $17^{\text {th }}$ ed, Washington DC. Batcher OM, PA Deary and EH Dawson. 1956.Cooking quality of 26 varieties of milled rice. Cereal Chem. 34:277-285. Bhattacharya KR. 2011. Rice quality: A guide to rice properties and analysis. $1^{\text {st }}$ ed, Woodhead Publishing Limited. New Delhi, India. 
Danbaba N, JC Anounye, AS Gana, ME Abo and MN Ukwungwu. 2011. Grain quality characteristics of Ofada rice (Oryza sativa L.): Cooking and eating quality. International Food Research Journal. 18: 629-634.

Fujino Y. 1978. Rice lipids. Cereal Chem. 55:559.

Grist DH. 1975. Nutritive value of rice. In: Rice. $5^{\text {th }}$ ed, Longman group, U K.

He GC. 1989. Study on rice grain quality in the aspect of radial differences of rice starchwith endosperm. PhD Dissertation. The United Graduate School of Agriculture Science, Ethime University, Japan.

Houston DF and GO Kohler. 1970. Nutritional properties of rice. National Academy of Science.Washington DC.

Iturriga L, B Lopez and M Anon. 2004. Thermal and physicochemical characterization of seven Argentine rice flours and starches. Food Res. Intl. 37(5):439-447.

Joshi ND, D Mohapatra and DC Joshi. 2013. Varietal selection of some indica rice for production of puffed rice. Food Bioproc. Technol.7:299-305

Juliano BO and Bechtel. 1985. Polysaccharides, protein, and lipids of rice. Rice Chemistry and Technology. 2:59-174. IRRI, Los Banos, Laguna, Philippnes.

Juliano BO and CM Perez. 1983. Major factors affecting cooked milled rice hardness and cooking time. J. Texture Stud. 14:235-243.

Juliano BO, GM Bautista, JC Lugay and AC Reyes. 1964. Studies on the physicochemical properties of rice. J. Agric. Food Chem.12:131-138

Juliano BO. 1972. A simplified assay for milled rice amylose. Cereal Sci. 16: 324-326.

Juliano BO. 1985. Criteria and tests for rice grains qualities. Rice Chemistry and Technology. 2:91-111. IRRI, Los Banos, Laguna, Philippnes.

Kent NL. 1983. Technology of cereals. Third Edition. Pergamon Press Ltd, New York. pp.27-48.

Lamberts L, ED Bie, GE Vandeputte, WS Veraverbeke,V Derycke and JA Delcour. 2007. Effect of degree of milling on color and nutritional properties of rice. Food Chemistry. 100:1496-1503.

Marco C and CM Rosell. 2008. Effect of different protein isolate and transglutaminase on rice flour properties. J Food Eng. 84(1):132-139.

MoAD. 2013. Statistical Information on Nepalese Agriculture, 2012/13. Ministry of Agricultural Development, Singh Durbar, Kathmandu, Nepal.

MoAD. 2015. Rice varietal mapping in Nepal: Implication for development and adoption. Crop Development Directorate, Department of Agriculture Development, Ministry of Agricultural Development, Government of Nepal, Kathmandu; pp.1-6

Mohapatra D and S Bal. 2007. Effect of degree of milling on specific energy consumption, optical measurements and cooking quality of rice. Journal of Food Engineering. 80:119-125.

NARC. 2014. Released and registered crop varieties in Nepal (1960-2013). Communication, Publication and Documentation Division (CPDD), Nepal Agricultural Research Council (NARC), Khumaltar, Lalitpur; pp.4-6.

Paramita B, RS Singhal and PR Kulkarni. 2002. Review Basmati rice: A review. International Journal of Food Science and Technology.37:1-12.

Payakapol, L A Moongngarm, N Daomukda and A Noisuwan. 2010. Influence of degree of milling on chemical compositions and physicochemical properties of jasmine rice. International Conference on Biology, Environment and Chemistry.1:83-86.

Pillaiyar P. 1988. Quality of rice: Rice post production manual. Wiley Eastern Ltd, New Delhi, India.

Resurreccion AP, BO Juliano and Y Tanaka. 1979. Nutrient content and distribution in milling fractions of rice grain. J. Sci. Food Agri. 30:475-81.

Rosniyana A, IH Rukundin and SA Shariffah Norin. 2006. Effects of milling degree on the chemical composition, physicochemical properties and cooking characteristics of brown rice. J. Trop. Agric. And Fd. Sc. 34(1):37-44.

Sabularse VC, JA Liuzzo, RM Rao and RM Grodner. 1991. Cooking quality of brown rice as influenced by gamma irradiation, variety, and storage. J. Sci. Food Agri. 56(1):96-98.

Saleh M and JF Meullenet. 2013. Contour presentation of long grain rice degree of milling and instrumental texture during cooking. International Food Research Journal. 20(3):1337-1344.

Siebenmorgen TJ and H Sun. 1994. The relation between milled rice surface fatconcentration and degree of milling as measured with commercial milling meter.Cereal Chem. 71(4):327-329.

Singh N, L Kaur, SN Singh and KS Sekhon. 2005. Physicochemical, cooking and textural properties of milled rice from different Indian rice cultivars. Food Chemistry. 89:253-259.

Subedi U, R Karki, A Mishra and MB Shrestha. 2016. Quality assessment of some rice varieties newly adopted in Nepal.J. Food Sci. Technol. Nepal. 9:48-54.

Suksomboon A and O Naivikul O. 2006. Effect of dry and wet milling process on chemical, physicochemical properties and starch molecular structure of rice starches. Kasetsart J. Nat. Sci. 40:125-134.

Thapa MJ, MB Shrestha, R Karki and CM Bhattarai. 2011. Study on milling recovery and quality of rice (head rice) with different degree of polishing. Agronomy Journal of Nepal. 2:88-92.

Thomas R, R Bhat and W Nadiah. 2013. Physiochemical properties, proximate composition, and cooking qualities of locally grown and imported rice varieties marketed in Penang, Malaysia. International Food Research Journal. 20(3):13451351.

Tran TU, K Suzuki, H Okadome, S Homma and K Ohtsubo. 2004. Analysis of the tastes of brown rice and milled rice with different milling yields using taste sensing system. Food Chemistry. 88:557-566. 
Varavinit S, S Shobsngob, W Varanyanondh, P Chinachoti and O Naivikul. 2003. Effect of amylose content on gelatinization, retrogradation and pasting properties of flours from different cultivars of Thai rice. Starch. 55:410-415.

Watt BK and AC Merrill. 1963. The composition of foods, raw, processed, prepared. Agricultural handbook-8, Research service, USDA.

Xiang C, J Ren, XQ Zhao, ZS Ding, J Zhang, C Wang, JW Zhang, CA Joseph, Q Zhang, YL Pang, YM Gaoand and YY Shi. 2015. Genetic dissection of low phosphorous tolerance related traits using selected introgression lines in rice. Rice Sci. 22(6):264-274.

Yoshizawa K and Y Ogawa. 2004. Rice in brewing. In: Rice chemistry and technology (ET Champagne, Ed). Third Edition. pp.549-552. AACC, Inc. St. Paul, Minnesota, USA. 